\title{
生体膜の連続性と不連続性
}

\author{
小 林 俊 秀
}

東北大学理学部物理学教室 荬980 仙台市青葉区荒巻字青葉

\section{Continuity and Discontinuity of Plasma Membranes}

\section{Toshihide Kobayashi}

Department of Physics, Tohoku University, Aoba-ku, Sendai 980

\begin{abstract}
Polarized cells such as epithelial cells and polarized neurons are characterized by their cell surface organization in which proteins are segregated and maintained in distinct plasma membrane domains. In order to examine the continuity of lipid bilayer between different plasma membrane domains, a method has been introduced to fuse liposomes selectively to one domain of the cell surface using influenza hemagglutinin protein.

When liposomes containing fluorescent lipids were fused to the apical domain of epithelial Madin Darby canine kidney (MDCK) cells, diffusion of lipids to the basolateral surface was observed only when fluorescent lipids were distributed in the inner leaflet of the liposomes. On the other hand, when liposomes were fused to the axon of cultured hippocampal neurons, diffusion of neither inner nor outer leaflet lipids to the somatodendritic domain was observed. These results suggest that the epithelial cells and the neurons have different membrane barriers. In MDCK cells, newly synthesized plasma membrane proteins are segregated in trans Golgi network to be transported to either apical or basolateral domains. Recent data suggest the occurrence of subdomains enriched with apical proteins and glycosphingolipids in the Golgi apparatus.
\end{abstract}

Key words: Epithelial cells, Hippocampal neurons, Membrane domains; Tight junction, Domain-specific fusion, Trans-Golgi network

\section{1.はじめに}

1972 年に Singer と Nicolson によって提出された生 体膜の流動モザイクモデル12 ${ }^{12)}$ は, 膜タンパク質がリン 脂質二重層の一様な海の中に浮かんでいるというもので あった.このモデルは多くの現象を説明したが, 同時に 生体膜は流動モザイクモデルで示されたよりもはるかに 複雑であることも認識されるようになってきた，その 1 つの例は細胞膜中での異なったドメインの存在である. 上皮細胞やニューロンなどの極性を持った細胞の形質膜
では膜タンパク質は異なったドメインに局在しており互 いに混ざり合うことはない. 最近のデータはこれらの細 胞には不連続な 2 つ脂質二重層が存在していることを 示唆している.

\section{2. 上皮細胞の膜構造}

上皮細胞の形質膜は 2 つのドメインより構成されてい る・先端 (apical) ドメインは管腔側に面しており, 側 底ドメインは血管側に接している. 2 つのドメインは夕 


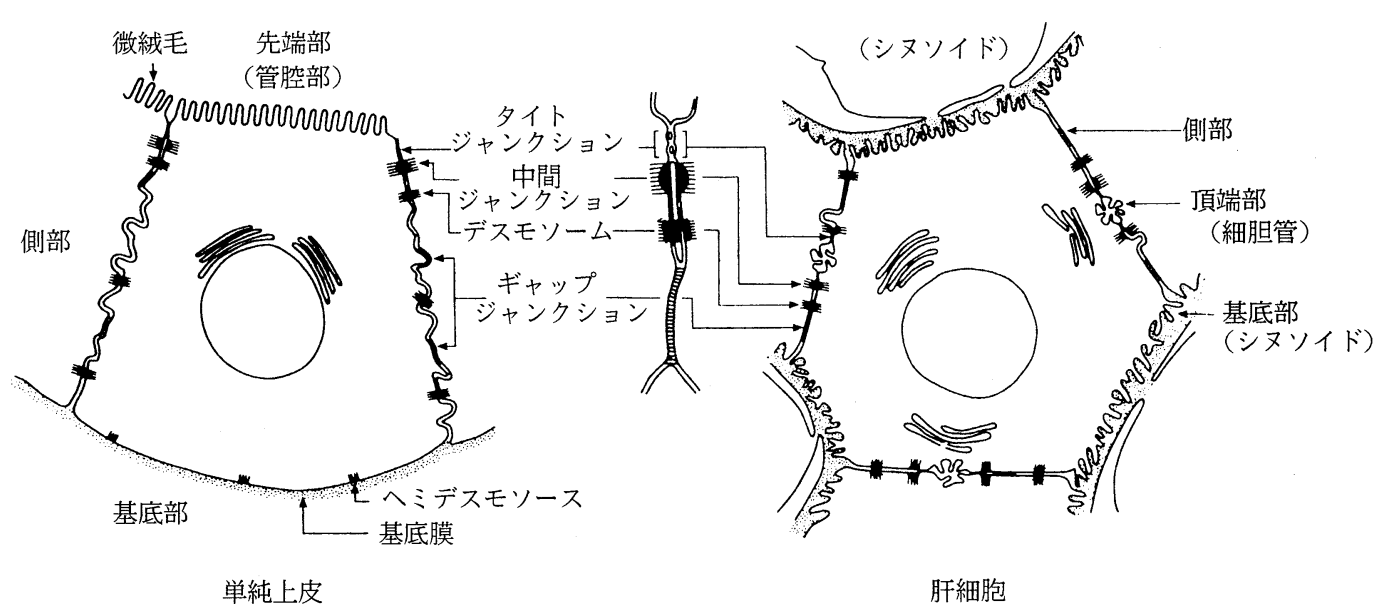

Fig. 1 単純上皮および肝細胞の形態 ${ }^{3)}$

Table 1 肝細胞と MDCK 細胞での種々のマーカーの各ドメインへの分布 ${ }^{3)}$

\begin{tabular}{|c|c|c|c|c|}
\hline マーカー & 細胞 & $\begin{array}{l}\text { 側底ドメイン: } \\
\text { 先端ドメインへ } \\
\text { のマーカーの分 } \\
\text { 布比 }\end{array}$ & $\begin{array}{l}\text { 側底ドメイン: } \\
\text { 先端ドメインで } \\
\text { のマーカーの表 } \\
\text { 面密度比 }\end{array}$ & 文献と方法 \\
\hline アシアロ糖タンパク受容体 & ラット肝細胞 & $85: 1$ & $14: 1$ & 4). フェリチン免疫電顕法 \\
\hline アシアロ糖タンパク受容体 & ラット肝細胞 & $51: 1$ & $7.5: 1$ & 5). 金標識リガンド \\
\hline 5' ヌクレオチダーゼ & ラット肝細胞 & $1.3: 1$ & $1: 4.5$ & 6). フェリチン免疫電顕法 \\
\hline VSV G タンパク & MDCK & $28: 1$ & $3.9: 1$ & $\begin{array}{l}\text { 7). サーフェスラジオイムノアッ } \\
\text { セイ }\end{array}$ \\
\hline インフルエンザ HA タンパク & MDCK & $1: 7$ & $1: 53$ & $\begin{array}{l}\text { 7). サーフェスラジオイムノアッ } \\
\text { セイ }\end{array}$ \\
\hline メチオニンの取り込み & MDCK & $>40: 1$ & $>5.5: 1$ & $\begin{array}{l}\text { 8). タンパク質へのメチオニンの } \\
\text { 取り込み }\end{array}$ \\
\hline トランスフェリン受容体 & MDCK & $>300: 1$ & $>41: 1$ & $\begin{array}{l}\text { 9). トランスフェリンに依存した } \\
\text { 鉄の取り込みの比 }\end{array}$ \\
\hline
\end{tabular}

イトジャンクションによって分離されている. Fig. 1 に 腎臓や小腸などで見られる単純上皮細胞と肝細胞の構造 を示した. たとえば小腸上皮では栄養は先端側から側底 側に輸送されるが，このような方向性を持った輸送をお こなうためには, 輸送タンパク質が 2 つ膜ドメインで 異なった分布をしていることが必須である. Table 1 に いくつかのタンパク質の細胞表面での分布を肝細胞およ びイヌ腎臓由来の培養上皮細胞である MDCK (MadinDarby canine kidney) 細胞について示した. ここに 挙げた側底面のタンパク質は絶対量で $97 \%$ 以上が側底 面に分布しているが, 先端面のタンパク質は側底面への 分布も見られる. しかし表面積あたりの密度を見ると,
たとえばインフルエンザウイルスのヘマグルチニンは 50 倍以上先端側に濃縮されている. 先端ドメインと側底 ドメインでは脂質の分布も異なっている. Table 2 に 示すように, どちらの形質膜ドメインにもいずれの脂質 も見られるが, 先端ドメインでは糖脂質の割合が高く, リン脂質は少ない, 側底ドメインのリン脂質の主なもの はホスファチジルコリンである. タイトジャンクション は先端ドメインと側底ドメインの境目に存在し，隣接す る細胞をつないでいる. 電子顕微鏡で見ると, タイトジャ ンクションの部分には膜内粒子が帯状に連なった構造が 見られる. カルシウム濃度を下げてタイトジャンクショ ンを開くとタンパク質の一方の形質膜ドメインへの偏っ 
Table 2 小腸上皮細胞での先端ドメインと側底ドメインへの脂質の分布 ${ }^{10)}$

\begin{tabular}{lcc}
\hline & $\begin{array}{c}\text { 先端ドメイン } \\
(\mathrm{mol} \%)\end{array}$ & $\begin{array}{c}\text { 側底ドメイン } \\
(\mathrm{mol} \%)\end{array}$ \\
\hline スフィンゴ糖脂質 & $37.1 \pm 9.3$ & $19.4 \pm 12.6$ \\
リン脂質 & $32.1 \pm 6.5$ & $52.4 \pm 12.7$ \\
ホスファチジルコリン & $8.7 \pm 3.7$ & $31.6 \pm 2.0$ \\
コレステロール & $30.8 \pm 3.1$ & $28.2 \pm 3.0$ \\
コレステロール/リン脂質 & $0.98 \pm 0.13$ & $0.61 \pm 0.21$ \\
$(\mathrm{~mol} / \mathrm{mol})$ & & \\
\hline
\end{tabular}

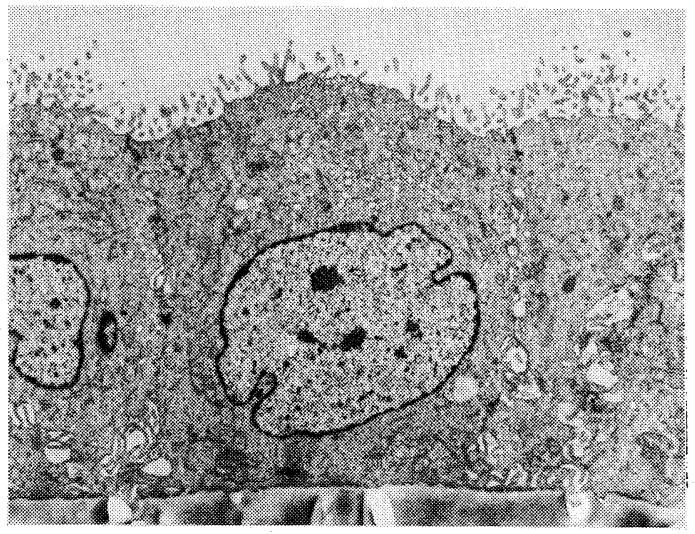

Fig. 2 メンブレンフィルターに生育した MDCK 細胞の電子顕微鏡像 ${ }^{12}$

た分布が失われること，また培養上皮細胞では細胞同士 が隣接してタイトジャンクションを形成することがタン パク質の各ドメインへの分布に必要であることから，夕 イトジャンクションが各々の形質膜ドメインの形成之維 持に重要な役割を果たしていると考えられているが，夕 イトジャンクションの組成や構造は良くわかっていな い. 繊維芽細胞に E-カドヘリンを発現させると $\mathrm{Na}^{+}$, $\mathrm{K}^{+} \mathrm{ATP}$ アーゼはカドヘリンに依存した細胞間の結合部 位に局在するようになる ${ }^{11)}$ 。この分布は上皮細胞での $\mathrm{Na}^{+}, \mathrm{K}^{+} \mathrm{ATP}$ アゼの分布と類似していることから, ある種のタンパク質の局在化はカドヘリンによって直接 誘起されていると考えられる.

上皮細胞の形質膜ドメインの形成や維持の機構につい ては MDCK 細胞を用いた多くの研究がある. MDCK 細胞をメンブレンフィルター上で生育させると, 細胞密 度の上昇に伴いタイトジャンクションが形成され, 培地 側に微繊毛を持った先端ドメイン，フィルター側に側底 ドメインが配列する (Fig. 2). MDCK 細胞に水泡性口 内炎ウイルス (Vesicular Stomatitis Virus, VSV) を
感染させると，ウイルス粒子は側底面から出芽する，一 方インフルエンザウイルスは先端面から出芽する ${ }^{13)}$. この発見以来, ウイルスタンパク質をマーカーとした MDCK 細胞の膜形成の研究が数多く行われるように なった. MDCK 細胞にインフルエンザウイルスと VSV を感染させると, どちらのウイルスの膜タンパク質も粗 面小胞体，シス，メディアルゴルジ体を経て，.トランス ゴルジネットワークまでは同様に輸送される.このこと から，MDCK 細胞では，トランスゴルジネットワーク で先端面と側底面へのタンパク質の振り分けが行われて いると考えられている. 一方 MDCK 細胞をカルシウム 濃度の低い培地で培養し, タンパク質を各々の形質膜ド メインに一様に分布させたのち, 高カルシウムの培地に 移す之, タイトジャンクションが形成され, 既存のタン パク質の各々のドメインへの再編成が観察される.この 場合には細胞骨格系の再編成を伴う ${ }^{14)}$.

\section{3. 上皮細胞膜の連続性と不連続性}

上皮細胞膜の 2 つの形質膜ドメインの脂質二重層の連 続性は, Dragsten ら ${ }^{15)} に よ り$ 最初に調べられた。彼 らは種々の蛍光標識した脂質類似体 (Fig. 3) を培養上 皮細胞の一方のドメインに挿入したときに，それらが夕 イトジャンクションを越えて反対側のドメインに移行す るかどうかを測定した。 その結果, 測定した脂質類似体 はタイトジャンクションを越える脂質と越えない脂質の 2 つのグループに分けられた. 同時に測定したこれらの 脂質類似体の拡散定数は $3 \sim 13 \times 10^{9} \mathrm{~cm}^{2} \mathrm{~s}^{-1}$ の範囲の 值を示し，いずれの脂質類似体も加えたドメイン中で拡 散していた. Fig. 3 で AFC 16 と AFC 12 との差は炭化 水素鎖の鎖長の違いだけであり，親水性基と疎水性基と の大きさの比率が，タイトジャンクションの通過に重要 な役割を果たしていることが示唆される.これらの蛍光 


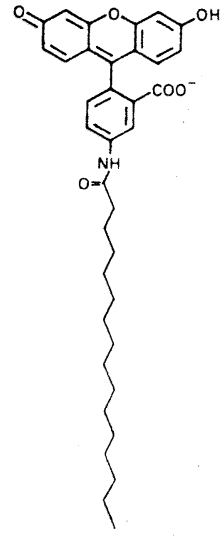

蛍光標識脂質類似体

タイトジャンクションの

通過

フリップーフロップ能
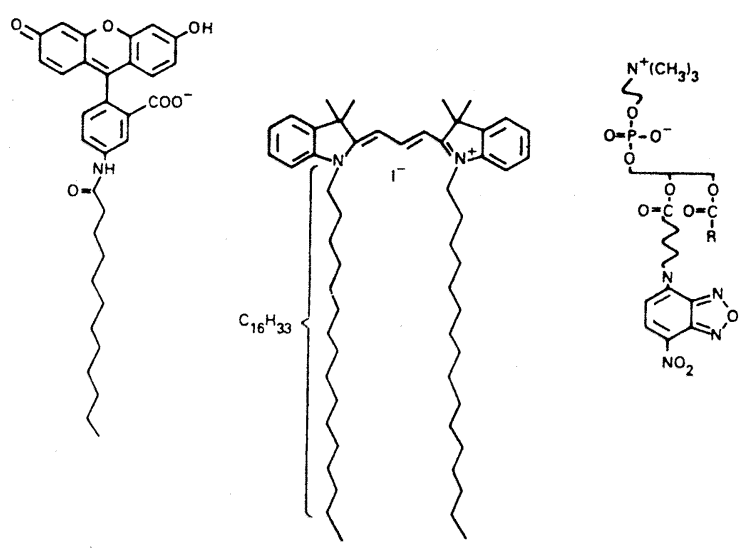

$\mathrm{AFC}_{12}$

$\operatorname{diIC}_{16}$

NBD-PC

Fig. 3 種々の蛍光標識脂質類似体のタイトジャンクションの通過能

A

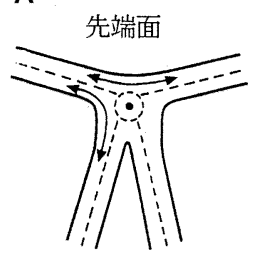

側底面
B

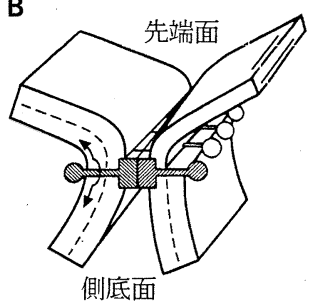

Fig. 4 タイトジャンクションの 2 つのモデル

標識脂質は細胞膜ドメインの外層に挿入されるが，夕イ トジャンクションを通過できる脂質は, いずれも外層か ら内層へフリップーフロップするのに対して，通過でき ない脂質にはフリップーフロップ活性は見られなかっ た.これらの結果から, 彼らはタイトジャンクションは 2 つの形質膜ドメインの脂質二重層の外層の脂質に対し てはバリアーとなっているが，内層の脂質の動きは制限 されていないと考えた. しかし彼らが用いた脂質類似体 は膜間移行能を有しているため，一旦フリップーフロッ プで形質膜の内層に移行したのち, 側方拡散ではなく, 細胞質を拡散してこれらの脂質類似体が別の形質膜ドメ インへと移行した可能性は否定できない.

上皮細胞の形質膜ドメインの連続性についての異なっ たアプローチが van Meer と Simons によって報告さ れた ${ }^{16)}$. 彼らはインフルエンザウイルスを MDCK 細胞

に感染させると膜融合活性を有するウイルスのヘマグル チニンタンパクが先端ドメインに選択的に発現すること を利用して，蛍光標識リン脂質を含むりポソームを先端 ドメインに特異的に融合させ, 蛍光リン脂質が側底ドメ インへと移行するかどうかを測定した. 蛍光脂質として はフリップーフロップ活性を示さない $N$-(lissamine rhodamine B sulfonyl)-dioleoylphosphatidylethanolamine (N-Rh-PE) を用い, リポソームをへマグル チニンタンパクに特異的に結合させるため, ヘマグルチ ニンタンパクのレセプター活性を有する糖脂質 GD1a $\left(\mathrm{IV}^{3} \mathrm{Neu} 5 \mathrm{Ac} \alpha, \Pi^{3} \mathrm{Neu} 5 \mathrm{Ac} \alpha-\mathrm{Gg}_{4} \mathrm{Cer}\right)$ がリポソーム に加えられた。

蛍光標識リン脂質を内層にも外層にも含むリポソーム を先端面に融合させた場合には蛍光は側底面にも観察さ れた. しかし蛍光脂質の $85 \%$ を外層に含むりポソーム を融合させた場合には蛍光は先端面に留まり，側底面へ の移行は見られなかった。一方, 細胞をカルシウムを含 まない培地に移してタイトジャンクションを開けると, 先端面の蛍光脂質の側底面への移行が認められた. 彼ら の結果もまた上皮細胞の 2 つ形質膜ドメインの脂質二 重層は外層では不連続であり, 内層では連続しているこ とを示している.

タイトジャンクションの構造については Fig. 4 に示 したようなモデルが提出されている. その1つはタイト 


ステージ 1
ラメリ
ポーディア 微小突起の

ジャンクションの中心に脂質のシリンダー構造があると するものである ${ }^{17,18)}$ (Fig. 4A).このモデルでは先端ド メイン之側底ドメインの脂質二重層の細胞質側は連続し ているが，外層はタイトジャンクションによって分離さ れている. 一方隣接した細胞の二重層の外層同士は連続 している.もう1つのモデル16) (Fig. 4B) では, タイ トジャンクションは膜を貫通したタンパク質でできてお り，それらのタンパク質によって細胞膜の外層および細 胞間の拡散が制限されている.上の実験で得られた結果 はどちらのモデルによっても説明できる. 2 つのモデル の違いは，細胞間で形質膜が連続しているかどうかとい う点である.この点について検討するため, van Meer らは糖脂質組成の違う MDCK I と MDCK II の 2 つの 細胞を同一フィルター上に培養し, MDCK II だけが発 現しているフォルスマン抗原 (GalNAc $\alpha 1-3$ GalNAc $\beta 1$ $\left.-3 \mathrm{Gal} \alpha 1-4 \mathrm{Gal} \beta 1-4 \mathrm{Glc} \beta 1-1^{\prime} \mathrm{Cer}\right)$ に対する抗体を用 いて細胞を染色した ${ }^{19)}$. 抗体は一様には分布せず，ほぼ $50 \%$ の細胞が染色された．この結果は細胞間での脂質 の拡散が起こっていないことを示している，彼らはまた
低濃度のインフルエンザウイルスに感染させた MDCK 細胞を用いて，一部の細胞にだけ蛍光標識脂質を含むリ ポソームを融合させ，蛍光脂質の他の細胞への拡散を見 たが，蛍光は一部の細胞にだけ観察された。これらの結 果はタイトジャンクションが Fig. 4A のような構造で はないことを示している。

\section{4. ニューロン膜の連続性と不連続性}

ニューロンもまた異なったタンパク質組成を有する形 質膜ドメインを形成している。ニューロンの膜構造は上 皮細胞に比べてはるかに複雑だが， ある種のニューロン では形質膜は大きく 2 つのドメイン一軸索および樹状突 起／細胞体一に分けられる，筆者らは培養ラット胎仔海 馬ニューロンを用いて，ニューロンの形質膜の連続性に ついて解析した。

ラット胎仔の海馬より調製したニューロンをグリア細 胞の存在下で培養すると, まずはじめに数本の短い突起 が現れ(ステージ 2$)$, そのうちの 1 本が急速に成長し， 


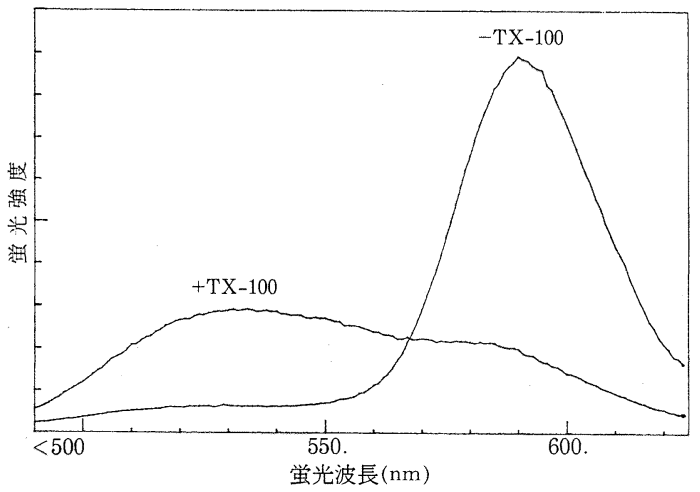

Fig. $6 N$-NBD-PE, $N$-Rh-PE を各々 1\%ずつ 含む DOPC リポソームの TX-100 の有無 での蛍光スペクトル. 励起波長は $470 \mathrm{~nm}$.

軸索となる (ステージ 3 ). ついで他の突起が樹状突起 を形成する(ステージ4).ささらに軸索は他のニューロ ンの樹状突起や細胞体とシナプスを形成する（ステージ 5) ${ }^{20)}$ (Fig. 5). タンパク質の異なった膜ドメインへの 局在化はニューロンでも観察されている．たとえばス テージ 5 のニューロンにVSV を感染させると, VSV のGタンパク質は細胞体と樹状突起に観察されるが, 軸 索には検出されない，一方インフルエンザウイルスを ニューロンに感染させると，インフルエンザのへマグル チニンは軸索に発現する ${ }^{211}$ ．極性をもったタンパク質の 分布はニューロンの分化に依存して起こり，ステージ 3 のニューロンではこれらのタンパク質は形質膜に一様に 分布する. Table 3 にいくつかのタンパク質の MDCK 細 胞之, ニューロンでの形質膜での分布を比較した ${ }^{12)}$. この表からわかるように，上皮細胞の先端ドメインと ニューロンの軸索，また上皮細胞の側底ドメインと ニューロンの樹状突起／細胞体との間には類似したタン パク質の分布が見られる。ニューロンにおける脂質の細 胞内分布はわかっていない.

ニューロンにはタイトジャンクション様の構造は存在 しない. それでは，ニューロンの各々のドメインのタン パク質はどのようなメカニズムで混ざり合いを避けてい るのであろうか？，大きく分けて 2 つのメカニズムが考 えられる.1つはタンパク質の動きが他のタンパク質と の強い相互作用によって大きく制限を受けている場合で ある. 赤血球の膜タンパク質の細胞質側で強く相互作用 している裏打ちタンパク質の存在が良く知られている. この場合，2つのドメインの間の脂質の移行は妨げられ ない，もうひとつの可能性は上皮細胞の場合之同様, 2
つのドメインの間で, 脂質二重層が不連続である場合で ある. 我々はインフルエンザウイルスに感染した培養 ニューロン細胞が，ヘマグルチニンを軸索に選択的に発 現するのを利用して, 上皮細胞表層の脂質二重層の連続 性を測定したのと同様の方法で，軸索ドメインと樹状突 起 / 細胞体ドメイン間の脂質の移行能を検討した ${ }^{33}$.

この実験では，まずニューロンにインフルエンザ Fawl Plague Virus (FPV) を感染させた。 感染後 7 8 時間 でへマグルチニンが軸索膜に発現する．この段階で蛍光 標識脂質を含むりポソームをへマグルチニン依存的に軸 索に結合させる.リポソームはジオレオイルホスファチ ジルコリン $(\mathrm{DOPC})$ にヘマグルチニンレセプターであ る GDla を含み, 蛍光脂質としては $N$-(7-nitro 2, 1 , 3-benzoxadiazol-4-yl) dioleoylphosphatidylethanolamine (N-NBD-PE) と N-Rh-PE を各々 $1 \%$ ず添 加した.このリポソームでは NBD（励起波長 $470 \mathrm{~nm}$, 蛍光波長 $535 \mathrm{~nm}$ ) から, ローダミン（励起波長 $563 \mathrm{~nm}$, 蛍光波長 $585 \mathrm{~nm}$ ) への共鳴エネルギー移動のため NBD の蛍光は観察されない. しかしリポソームがニューロン 之融合して蛍光脂質の密度が下がると, 共鳴エネルギー 移動は起こらなくなり, 蛍光が観察されるようになる ${ }^{34)}$. Fig. 6 は用いたリポソームの蛍光を非イオン性界面活 性剤である Triton X-100(TX-100) の存在の有無で測 定したものである。TX-100 が存在しない場合, NBD からローダミンへの共鳴エネルギー移動により $470 \mathrm{~nm}$ の励起ではNBD の蛍光はほとんど観察されず，ローダ ミンの蛍光が観察されるが，TX-100によって脂質が希 釈されると NBD の蛍光が観察される.

リポソームを低温 $\left(8^{\circ} \mathrm{C}\right)$ でニューロンに作用させる と，リポソームは軸索に選択的に結合する。このときの 位相差および蛍光顕微鏡像を Fig. 7, A〜Cに示した. 軸索に沿ったローダミンの蛍光が観察されるが, この段 階では NBD の蛍光は非常に弱い. $8^{\circ} \mathrm{C}$ での処理ののち, 過㮃のリポソームを洗い, $37^{\circ} \mathrm{C}, \mathrm{pH} 5.0$ の培地で 1 分 間処理することによりリポソームは軸索に融合する。融 合後の位相差および蛍光顕微鏡像を Fig. 7, D F に示 す. 融合の結果, 強い NBD の蛍光が観察されるように なる. 興味深いことに, 融合ののちも蛍光は軸索に留まっ ており, 軸索と樹状突起 / 細胞体の間に脂質の側方拡散 の障壁があることが示唆された. リポソームに蛍光脂質 の代わりに水溶性の蛍光物質カルセインを封入すると, カルセインはニューロンの細胞全体を蛍光標識する (Fig. 7, G, H). このことはニューロンの細胞膜は不 

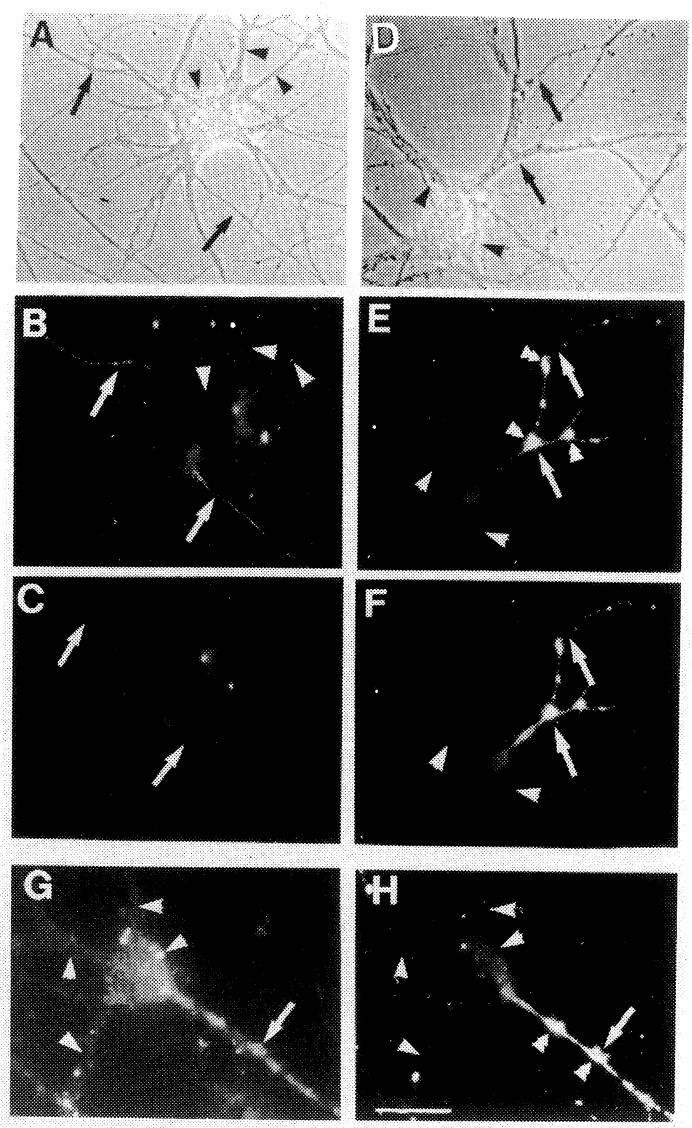

Fig. 7 -NBD-PE と N-Rh-PE を含むりポ ソームのインフルエンザウイルスに感染 したニューロンへの結合 $(\mathrm{A} \sim \mathrm{C})$ と融合 $(\mathrm{D} \sim \mathrm{F})$.

位相差顕微鏡像 $(\mathrm{A}, \mathrm{D})$, ローダミンチャ ンネルで見た蛍光顕微鏡像 $(\mathrm{B}, \mathrm{E})$ および $\mathrm{NBD}$ チャンネルで見た蛍光顕微鏡像 $(\mathrm{C}, \mathrm{F})$ を示す. $\mathrm{G}, \mathrm{H}$ はカルセインと $N-\mathrm{Rh}-\mathrm{PE}$ を含むりポソームをニューロ ンに融合させたときのカルセイン $(\mathrm{G})$ と ローダミン $(\mathrm{H})$ の蛍光を示す.

連続だが, 細胞質の拡散の障壁はないことを示している. つぎに軸索に融合した蛍光標識脂質の軸索膜上での側方 拡散を蛍光退色回復法を用いて測定した (Fig. 8). 実験 は共焦点レーザー顕微鏡上で軸索に $5 \mu \mathrm{m}$ 幅の $488 \mathrm{~nm}$ のレーザーを $300 \mathrm{msec}$ 照射したのち, 室温での蛍光の 回復をビデオカメラに撮り, コンピュータ解析した. 写 真はレーザー照射前 (A), 照射 1 秒後 (B) および 5 秒後 (C) の蛍光顕微鏡像を示す. 蛍光退色は 1 つの実験では 5 秒間で $40 \%$ 回復し (Example B), 別の実験では 12
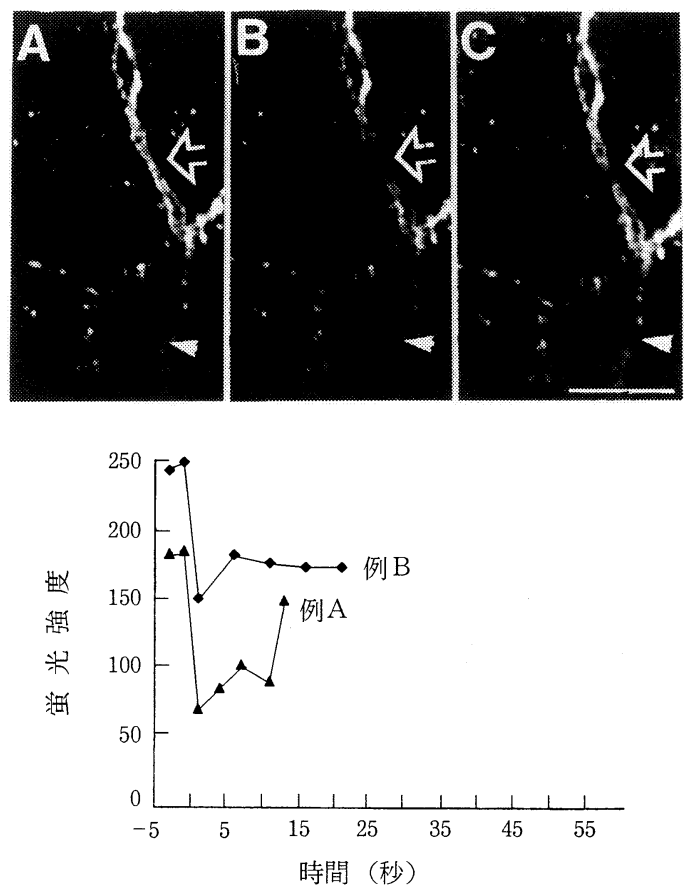

Fig. 8 NBD チャンネルでの軸索の蛍光退色回 復. 個々の図の説明は本文参照.

秒間に $70 \%$ 回復した (Example A).このことから蛍 光脂質の軸索上での動きは制限されていないことがわか る.

ここまでの結果は，ニューロンの細胞表面の脂質二重

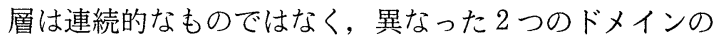
間で不連続なものであることを示唆している．上皮細胞 の場合にはタイトジャンクションは, 膜の外層のみの脂 質の動きを制限していた。ニューロンの実験で使用した リポソームでは, 蛍光脂質は膜の外層と内層に対称に分 布している. しかし樹状突起／細胞体の大きな表面積を 考慮すると，ニューロンの細胞表面の脂質二重層に対す る膜障壁が膜の外層の脂質に対してだけ働いていても, 内層の蛍光は樹状突起／細胞体の広い表面積のために希 釈されてしまい, 蛍光顕微鏡下で観察されないという可 能性も否定できない. なお, 細胞質側に露出していない, グリコシルホスファチジルイノシトール (GPI) アン カーされているタンパク質である Thy-1 が軸索に局在 していることを考えると, 膜障壁が脂質二重層の内層の 脂質にだけ働いているという可能性は低いように思われ る.

膜障壁が脂質二重層の外層にだけ働いているという可 
A
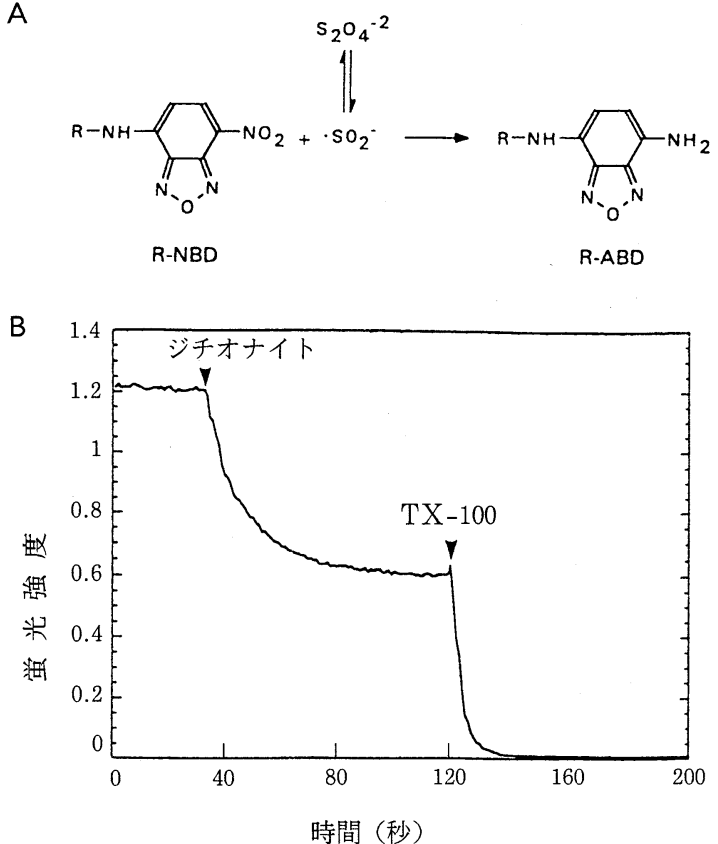

Fig. 9 ジチオナイトによる NBD の蛍光の消去.

(A) ジチオナイト $\left(\mathrm{S}_{2} \mathrm{O}_{4}{ }^{-2}\right)$ により $\mathrm{NBD}$ は 7-amino-2, 1, 3-benzoxadiazol-4-yl (ABD) に還元され蛍光を失う.

(B) N-NBD-PE が脂質二重層の内層之 外層に対称的に分布しているリポソームに ジチオナイトを加えると外層の NBDだ けが消去される，TX-100でリポソーム を壊すとすべての NBD の蛍光が退色す る.

能性について検討するため, 蛍光脂質が脂質二重層の内 層にだけ分布しているリポソームを作製した。このため に, 最近発表されたジチオナイトによるNBD の蛍光消 去法が用いられた ${ }^{35)}$. NBD はジチオナイトによって蛍 光が消去される (Fig. 9) が, ジチオナイトは水溶性の ため N-NBD-PE を含むりポソームに作用させると,

リポソームの外層の蛍光だけが消去される．このような リポソームを軸索に融合させた. Fig. 10 に位相差およ び蛍光顕微鏡像を示すが，この場合にも蛍光は軸索に留 まっており，ニューロンの膜障壁は脂質二重層の外層之 内層の両方に対して働いていることが示唆された．また 蛍光脂質を膜の外層にも内層にも含むりポソームを軸索 に融合させたのち, 細胞をジチオナイト処理して細胞外 層の蛍光を消去しても，蛍光は軸索のみに観察された (Fig.11).これらの結果は上皮細胞と二ューロンでは異 なった種類の膜障壁が存在することを示唆している.
A
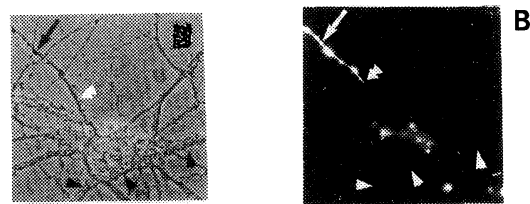

Fig. 10 脂質二重層外層の蛍光を消去したリポ ソームの軸索への融合.

$\mathrm{A}$ に位相差顕微鏡像, B に蛍光顕微鏡像 を示す.
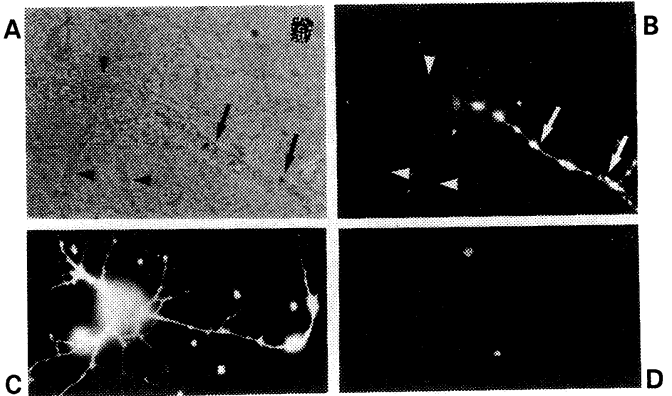

Fig. 11 NBD を脂質二重層の内層と外層に対称 的に含むりポソームを軸索に融合させた のち, 細胞をジチオナイト処理した.

$\mathrm{A}$ は位相差顕微鏡像, B は蛍光顕微鏡像 を示す. C. D はニューロンでのジチオナ イトによる蛍光消光の効率を見たもので ある.ニューロンに $N-\mathrm{NBD}-\mathrm{PE}$ のエ夕 ノール溶液を加えると蛍光は細胞膜の外 層全体に分布する $(\mathrm{C})$ が，ジチオナイト を加えると蛍光は観察されなくなる (D).

ニューロンでの形質膜の不連続性を維持する機構がどう いうものであるのかはわかっていない.ニューロンのナ トリウムポンプは細胞体と軸索の根元付近に局在する が，軸索の根元付近に局在するタンパクの膜上での動き は，極めて遅いことが報告されている ${ }^{29)}$.このような タンパクのクラスターは膜障壁の 1 つの候補かも知れな い.

\section{5. 極性細胞の膜形成}

上皮細胞やニューロンなどの極性をもった細胞膜の形 成は, 繊維芽細胞などの膜形成に比べ複雑である.MD $\mathrm{CK}$ 細胞ではトランスゴルジネットワークから異なった 小胞を介して先端タンパク質と側底タンパク質が各々の ドメインに輸送されると考えられている。ニューロンで のタンパク質の振り分け機構は分かっていない. 形質膜 タンパク質は膜結合リボソームで合成されたのち，小胞 

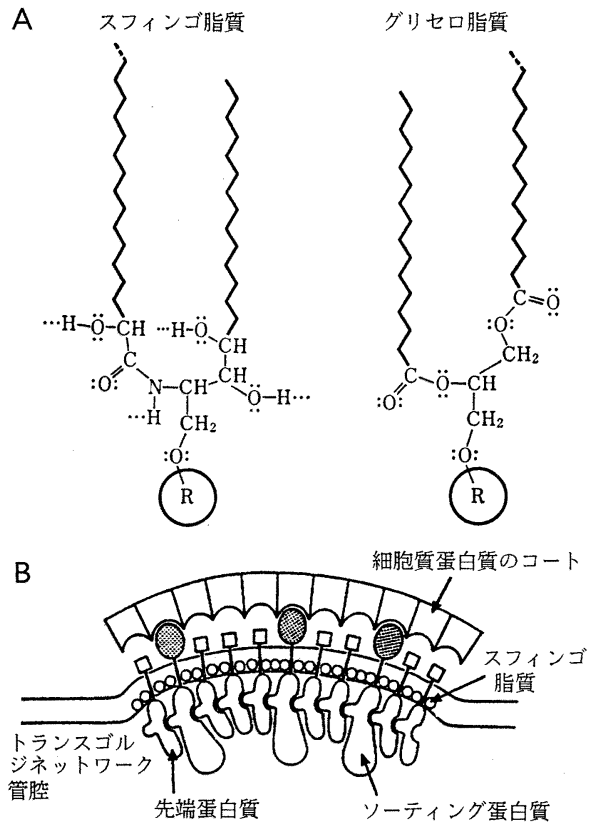

Fig. 12 トランスゴルジネットワークにおける水 素結合を介したスフィンゴ脂質ドメイン の形成.

(A) スフィンゴ脂質とグリセロ脂質の水 素結合のドナーとアクセプターの違い ${ }^{40)}$.

(B) トランスゴルジネットワークにおけ る先端プレカーサーマイクロドメインの 形成 $\left.{ }^{10}, 39\right)$. スフィンゴ脂質は脂質二重 層の管腔側でクラスターを形成する. 仮 想上のソーティングタンパク質は膜を貫 通して細胞質側でコートタンパク質と相 互作用している．先端タンパク質は先端 タンパク質同士，あるいはソーティング タンパク質と管腔側で相互作用している と仮定される.

体, ゴルジ体を経て小胞輸送で形質膜に運ばれるが, 脂 質の輸送経路ははっきりしていない，分裂細胞等を用い た実験からは，グリセロリン脂質であるホスファチジル エタノールアミンや, ホスファチジルコリンは小胞に依 存しない経路が主経路であり，スフィンゴ脂質は小胞輸

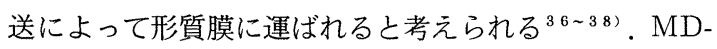
$\mathrm{CK}$ 細胞の先端ドメインがスフィンゴ脂質に富むこと, またスフィンゴ脂質は容易に水素結合を形成することか ら Simons らは先端ドメインのタンパク質とスフィン ゴ脂質が, トランスゴルジネットワークでサブドメイン を形成し, それが先端ドメインへの輸送小胞となって先 端ドメインへと輸送されるという仮説を提出してい
膜 (MEMBRANE), Vol. 17 No. 6 (1992)

377

る ${ }^{10.39)}$ (Fig. 12). このモデルに対する実験的な証拠は なかったが, 最近になって, 先端タンパク質とスフィン ゴ脂質とのドメインの存在を示唆する結果が報告され た ${ }^{41)}$. GPI アンカーを持つタンパク質は, MDCK 細 胞では先端ドメインに輸送される. Brown とRose は GPI アンカーされたタンパク質であるヒト胎盤アルカ リホスファターゼ(PLAP) で形質転換した MDCK 細 胞で, PLAP は生合成部位から先端ドメインへの輸送 に伴って TX-100に不溶性になることを見いだした. $\mathrm{PLAP}$ は小胞体でアスパラギンの $\mathrm{NH}_{2}$ 基にオリゴ糖を 結合するが，小胞体で結合したオリゴ糖は試験管内でエ ンドグリコシダーゼ H (endoH) によって切断される.

しかし小胞輸送でタンパク質がメディアルゴルジまで輸 送されると, $N$-アセチルガラクトサミントランスフェ ラーゼ I とマンノシダーゼII の作用によって endoH 耐 性になる. endoH 感受性の PLAP はTX-100に可溶性 だが, endoH 耐性の PLAP は TX-100 不溶性画分に回 収された。このことは生合成された PLAP は, メディ アルゴルジを通過すると TX-100 に不溶性になること を示唆している. 電子顕微鏡像から TX-100 不溶性画 分は, 膜コンプレックスであることが示された. この画 分の脂質組成を調べたところかスフィンゴミエリンや糖 脂質が濃縮されており, リン脂質はほとんど回収されな かった. この実験からは PLAP とスフィンゴ脂質が 別々に TX-100 不溶性の aggregate を作っている可能 性を否定しきれないが，スフィンゴ脂質と先端タンパク 質とのマイクロドメインの形成を示唆する最初の報告と して興味深い.

\section{6. おわりに}

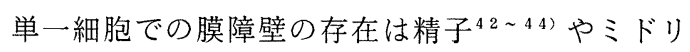
ムシ ${ }^{45 \sim 47)}$ のような他の細胞でも示唆されている. 脂 質二重層の動きがどのようなメカニズムで制限されてい るのかは今後検討していかなくてはならない. またこの ような形質膜上のドメインを形成するためにゴルジ体で サブドメインが形成されるとすれば，それはどのような 構造でよ゙のようなメカニズムによって形成されるのだろ うか? またゴルジ体にサブドメインが存在することをど のようにすれば証明できるだろうか. 今後の進展が待た れる.

本稿で紹介した筆者らのニューロンに関するデータは 
筆者がヨーロッパ分子生物学研究所 (ドイツ) 滞在中 Kai Simons 博士, Carlos G. Dotti 博士らとの共同研 究で得られたものである.

最後に, 本稿執筆の機会を与えて頂いた東北大学理学 部大木和夫教授に深く感謝致します.

\section{参考文献}

1) Singer, S. J. and Nicolson, G. L. (1972) Nature 175, 720

2) 大木和夫 (1988) 膜 13,62

3) Simons, K. and Fuller, S. D. (1985) Annu. Rev. Cell Biol. 1, 243

4) Matsuura, S., Nakada, H., Sawamura, T. and Tashiro, Y. (1982) J. Cell Biol. 95, 864

5) Hubbard, A.L., Wall, D.A. and Ma, A. (1983) J. Cell Biol. 96, 217

6) Matsuura, S., Eto, S., Kato, K. and Tashiro, Y. (1984) J. Cell Biol. 99, 2131

7) Pfeiffer, S., Fuller, S. D. and Simons, K. (1985) J. Cell Biol. 101, 470

8) Balcarova-Stander, J., Pfeiffer, S., Fuller, S. D. and Simons, K. (1984) EMBO J. 3, 2687

9) Fuller, S. D. and Simons, K. (1986) J. Cell Biol. 103, 1767

10) Simons, K. and van Meer, G. (1988) Biochemistry 27,6197

11) McNeill, H., Ozawa, M., Kemler, R. and Nelson, W. J. (1990) Cell 62, 309

12) Simons, K., Dupree, P., Fiedler, K., Huber, L., Kobayashi, T., Kurzchalia, T., Olkkonen, V., Pimplikar, S., Parton, R. and Dotti, C. G. (1992) Cold Spring Harbor Symp. Quant, Biol. in press

13) Rodriguez-Boulan, E. J. and Sabatini, D. D. (1978) Proc. Natl. Acad. Sci. USA 75, 5071

14) Rodriguez-Boulan, E. and Nelson, W. J. (1989) Science 245, 718

15) Dragsten, P. R., Blumenthal, R. and Handler, J. S. (1981) Nature 294, 718

16) van Meer, G. and Simons, K. (1986) EMBO J. 5, 1455

17) Kachar, B. and Reese, T.S. (1982) Nature 296, 464

18) Pinto de Silva, P. and Kachar, B. (1982) Cell 28,441

19) van Meer, G., Gumbiner, B. and Simons, K. (1986) Nature 322, 639

20) Dotti, C. G., Sullivan, C. A. and Banker, G. A. (1988) J. Neurosci. 8, 1454

21) Dotti, C.G. and Simons, K. (1990) Cell, 62, 63

22) Rodriguez-Boulan, E. and Pendergast, M.
(1980) Cell 20, 45

23) Dotti, C. G., Kartenbeck, J. and Simons, K. submitted.

24) Roman, L. M. and Garoff, H. (1986) J. Cell Biol. 103, 2607

25) Parton, R. G., Simons, K. and Dotti, C. G. (1992) J. Cell. Biol. 119, 123

26) Cameron, P. L., Sudhof, T. C., Jahn, R. and de Camilli, P. (1991) J. Cell Biol. 115, 151

27) Wilson, J. M., Fasel, N. and Kraehenbuhl, J.-P. (1990) J. Cell Sci. 96, 143

28) Dotti, C. G., Parton, R. G. and Simons, K. (1991) Nature 349, 158

29) Angelides, K.J., Elmer, L.W., Loftus, D. and Elson, E. (1988) J. Cell Biol. 106, 1911

30) Angelides, K. J. and Wible, B. (1992) Neuron, in press

31) Hammerton, R. W. and Krzeminski, K. A. (1991) Science 254, 847

32) Pietrini, G., Matteoli, M. and Caplan, M. J. (1991) J. Cell Biol. 115, 67a

33) Kobayashi, T., Storrie, B., Simons, K. and Dotti, C. G. (1992) Nature 359, 647

34) Kobayashi, T. and Pagano, R. E. (1988) Cell $\mathbf{5 5 ,} 797$

35) McIntire, J. C. and Sleight, R. G. (1991) Biochemistry 30, 11819

36) Kobayashi, T. and Pagano, R. E. (1989) J. Biol. Chem. 264, 5966

37) Kobayashi, T., Pimplikar, S. W., Parton, R. G., Bhakdi, S. and Simons, K. (1992) FEBS Lett. 300, 227

38）小林俊秀 (1991) 蛋白質核酸酵素 36,533

39) Simons, K. and Wandinger-Ness, A. (1990) Cell 62, 207

40) Pascher, I (1976) Biochim. Biophys. Acta 455, 433

41) Brown, D. A. and Rose, J. K. (1992) Cell 68, 533

42) Wolf, D. E. and Voglmayr, J. K. (1984) J. Cell Biol. 98, 1678

43) Wolf, D. E., Hagopian, S. S., Lewis, R. G., Voglmayr, J. K. and Fairbanks, G. (1986) J. Cell Biol. 102, 1826

44) Cowan, A. E., Myles, D. G. and Koppel, D. E. (1987) J. Cell Biol. 104, 917

45) Friend, D. S. and Fawcett, D. W. (1974) J. Cell Biol. 63, 641

46) Weiss, R. L., Goodenough, D. A. and Goodenough, U. W. (1977) J. Cell Biol. 72, 133

47) Hunnicutt, G. R., Kosfiszer, M. G. and Snell, W. J. (1990) J. Cell Biol. 111, 1605

（受付 1992 年 9 月 11 日） 